\title{
Integrated Model For Honyaku Learning Process In Japanese Literature Departement Of Andalas University
}

\author{
Rina Yuniastuti ${ }^{*}$, Rahtu Nila Sepni ${ }^{2}$ \\ Japanese Literature, Universitas Andalas ${ }^{1}$ \\ Japanese Literature, Universitas Andalas ${ }^{2}$ \\ \{rinayuniastuti@hum.unand.ac.id ${ }^{1}$, rahtunilasepni@hum.unand.ac.id ${ }^{2}$ \}
}

\begin{abstract}
Honyaku (translation) is a compulsory subject in Japanese Literature Department of Andalas University that aims to make students are able and skillful in translating Japanese text into Indonesian and vice versa. The classroom action research method was used in conducting this research. This method is used not only to solve learning problems in the classroom but also to improve the quality of learning in the Honyaku subject as a part of applied linguistics. The object of this research is the integrated model used in the Honyaku course. Furthermore, this study also discusses linguistic knowledge that can be involved in this learning model, including syntax, semantics, pragmatics and other competencies such as knowledge of Japanese society and culture. The results showed that the integrated model could improve student competence in the field of translation and develop lecturers' professional abilities to innovate in learning activities.
\end{abstract}

Keywords: integrated model; applied linguistics; translation

\section{Introduction}

Applied linguistics is a kind of linguistics which refers to the usage of the application of the language. One part of applied linguistics is translation (Honyaku). The competency expected from learning this subject is that students have the ability to translate well from Japanese to Indonesian and vice versa. This competency can be seen from the correct and acceptable translation results and can express their ideas logically and systematically, which shows that they have mastered Japanese well.

So far, the material given in the Honyaku course includes an introduction to translation along with its methods and techniques. However, this material does not provide satisfactory results for student learning outcomes. This is because the assessment process only refers to the results, not the process. One of the efforts made to improve student competence in Honyaku courses is to use an integrated model in the learning process.

According to Fogarty [2], an integrated model is a learning approach that deliberately links several aspects of a course. Psychologically integrated models can provide meaningful experiences for students, because students experience them directly and relate them to other 
concepts. This is consistent with the philosophy of I hear- I forget, I see- I remember, I do- I understand.

According to Sukayati in Ananda and Abdillah [1], the integrated model which has a role as a process is defined in some characteristics as follows:

1. Student-centered learning.

Integrated models provide flexibility for students to actively seek and find the concept of knowledge.

2. Emphasize the formation of understanding and meaning.

The integrated model examines a phenomenon from various aspects and its relationship with other concepts being studied so that learning activities become more meaningful.

3. Learning Through Direct Experience

In the integrated model, students will understand their learning outcomes according to the facts and events they experience, not just information from lecturers who teach courses. Lecturers act more as facilitators and catalysts while students act as actors.

4. Pay more attention to process rather than results.

In the integrated model, discovery inquri approach was developed which involved students actively in the learning process, starting from planning, implementation to the evaluation process.

5. Loaded with related loads

Integrated learning focuses on observing and studying a symptom or event from several courses at once, not from a compartmentalized perspective.

Honyaku (translation) is a complex activity that demands accuracy. As stated by Newmark [4], translation is translating a text into another language according to what the author intended. A translator is not only required to be able to master the source language and target language but must also be sensitive to social, cultural, political and emotional factors in order to be able to translate correctly. The main objective of translation is to produce a translation that is as close to the original as possible. However, in reality there are always things that cannot be translated properly. This can be due to differences in language structure, nuances and sociocultural points of view.

Meanwhile, translation according to Larson [3] does not only consist of a single activity, namely the transfer of the meaning of the source language into the target language, but also involves several stages. First, studying the lexicon, language structure, communication situations and cultural context of the source language. Second, carefully analyzing to determine its meaning. Third, reconstructing the same meaning by using lexicons and grammatical structures that are in accordance with the target language and cultural context. The process of translating the Larson model can be seen in the figure 1, 
SOURCE LANGUANGE

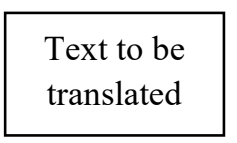

RECEPTOR LANGUAGE

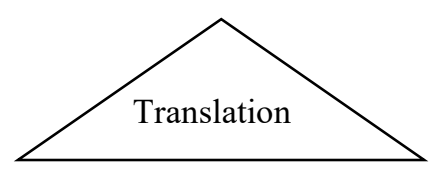

Re-express the meaning

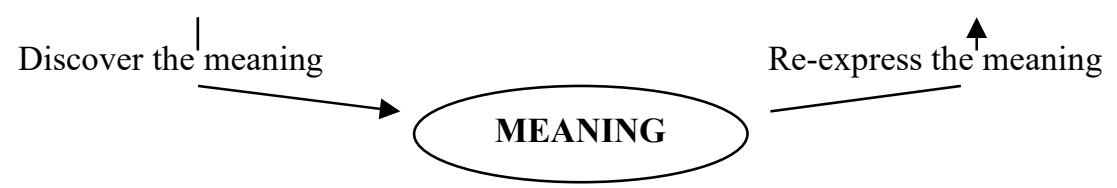

Figure 1. Translation process by Larson

In this study, the integrated subjects were Syntax, Semantic, Pragmatic and Nihonjijo. Syntax is the study of the rules governing the ways word, word group and phrases are combined to form sentences in a language. Meanwhile, semantic is the study the meaning of word, phrases and sentences. Pragmatic is a systemic way of explaining language use in context and Nihonjijo is the study of Japanese culture and society.

From the explanation above, this study discusses the application of an integrated model in the Honyaku course to improve student learning competencies.

\section{Methods}

The object of this research is an integrated model of Honyaku learning. The stages of this research are divided into two stages, as explained by Hopkins (1993), namely the planning stage accompanied by observation and the implementation stage. This research is focused on the planning stages which include orientation, planning, implementing actions, observation and reflection.

The steps of this research are: 1. Conducting a literary study of the integrated model and learning process of the Honyaku course. 2. Identify the concepts, skills developed in the course. 3. Developing an integrated model taking into account the characteristics of the Honyaku course. 4. Developing instruments for assessing quality, consisting of observation guidelines, tests, questionnaires and interview guidelines.

The data that has been obtained is tested for validation. The validation test is carried out using qualitative analysis techniques in the form of checking data and information obtained from students and lecturers.

\section{Results}

In the Japanese Literature Department of Andalas University, the Honyaku course is a compulsory course for semester VI students. In semester VI, students have received Syntax, Semantic, Pragmatic and Nihonjijo courses. Based on the translation process by Larson, the application of an integrated model in Honyaku learning by involving these subjects is defined in the table 1 below. 
Table 1. The application of an integrated model in Honyaku learning

\begin{tabular}{ll}
\hline \multicolumn{1}{c}{ Translation process } & \multicolumn{1}{c}{ Subject competence } \\
\hline $\begin{array}{l}\text { Studying the lexicon, grammatical } \\
\text { structure, communication situation and } \\
\text { cultural context of the source language. }\end{array}$ & Syntax, Semantic, Pragmatic dan \\
$\begin{array}{l}\text { Analyzing to determine its meaning } \\
\text { Reconstructing this same meaning in } \\
\text { the receptor language. }\end{array}$ & \begin{tabular}{l} 
Semantic, Pragmatic \\
Syntax, Semantic, Pragmatic and \\
\hline
\end{tabular} \\
\hline
\end{tabular}

Meanwhile, student responses to the application of an integrated model in Honyaku learning are in the table 2 .

Table 2. Student responses to the application of the integrated model

\begin{tabular}{clcc}
\hline No & \multicolumn{1}{c}{ Instrument } & Actual score & Criteria \\
\hline 1 & Integrated model makes me active in doing tasks & $71 \%$ & Good \\
2 & My motivation is increased with an integrated model & $84 \%$ & Good \\
3 & Integrated model makes it easier for me to understand & $75 \%$ & Good \\
& the subject matter & $71 \%$ & Good \\
4 & I became more confident in my own abilities & $75 \%$ & Good \\
5 & Integrated model allows me to express my opinion & $80 \%$ & Good \\
6 & Integrated model makes learning more effective & & \\
\hline
\end{tabular}

Table 3. Ideal score criteria

\begin{tabular}{ccc}
\hline No & \% Total score & Criteria \\
\hline 1 & $20.00-36.00$ & Not very good \\
2 & $36.01-52.00$ & Not good \\
3 & $52.01-68.00$ & Enough \\
4 & $68.01-84.00$ & Good \\
5 & $84.01-100$ & Very good \\
\hline
\end{tabular}

\section{Discussion}

From table 1 it can be explained that the translation process begins by learning the lexicon, grammatical structure, communication situations and the social and cultural context of the source language. In this process, subject competences that can be integrated are Syntax, Semantic, Pragmatic and Nihonjijo. The integration of Honyaku course material and Syntax can be applied to analyze the lexicon and grammatical structure of the source text language. The integration of Honyaku and Semantic course materials can be applied to search the meaning of words in the source text. The integration of Honyaku and Pragmatic course materials can be applied to analyze communication situations. The integration of Honyaku and Nihonjijo course materials can be applied to understand the social and cultural context of the source language, in this case the Japanese society and culture. Meanwhile, in the second stage, to be able to get the correct meaning from the source text, we can integrate Semantic and Pragmatic knowledge. The integration of the subject matter can be applied to get the exact meaning as intended by the source text. In the third stage, namely reconstructing meaning into the target language, Syntax, Semantic, Pragmatic and Nihonjijo competencies can be 
integrated again. The integration of this course material can be applied to obtain correct and acceptable translation results for the target language.

From table 2 it can be seen that the questions from the student response questionnaire to the integrated model are positive questions so that the answers also show positive things. Based on the actual score obtained an average of $76 \%$. From these results, the student responses are in good criteria because they are at a vulnerable value of 68.01-84.00.

\section{Conclusion}

The integrated model in this study produces a continuous learning process that is obtained through five courses which include Honyaku, Syntax, Semantic, Pragmatic and Nihonjijo. By implementing integrated learning, students can understand the material completely and meaningfully. The meaning of the learning outcomes can be obtained by students because they experience the process. The materials can be applied directly so that the expected competencies in the course can be achieved in the same learning activity.

With a positive response to the application of the integrated model, it is hoped that it can improve student competence, especially in translation skills. By paying attention to the continuity between one course and another, an integrated model is one solution to improve the quality of student translation results. Besides, it can also develop lecturers' professional abilities to innovate in learning activities.

Integrated models can be developed in other materials. Not only the five subjects have been integrated in this study. Other courses can also be combined with analyzing the competencies that must be achieved. Based on the results of the analysis, it will be known the similarities in skills, knowledge, and attitudes that will be achieved from these several courses.

\section{References}

[1] Ananda, R. dan Abdillah. 2018. Pembelajaran Terpadu (Karakteristik, Landasan, Fungsi, Prinsip dan Model). Medan: LPPPI

[2] Fogarty, R. 1991. How to Integrate the Curricula. Illionis: Skylight Publishing Inc.

[3] Larson, M.L. 1998. Meaning Based Translation. A Guide to Cross-Language Equivalence. Second Edition. New York: University Press of Amerika

[4] Newmark, Peter. 1988. A Textbook of Translation. U.K: Prentice Hall International Ltd. 